\title{
Effect of occupational risk factors in cancer incidence in Iran: a
} Systematic Review

\author{
Vida Zaroushani $\mathrm{PhD}^{1,2, *}$, Farahnaz Khajehnasiri $\mathrm{PhD}^{3}$ \\ 1. Department of Occupational Health Engineering, Faculty of Health, Qazvin University of Medical Sciences, Qazvin, Iran. \\ 2. Social Determinants of Health Research Center, Qazvin University of Medical Sciences, Qazvin. Iran. \\ 3. Department of Community Medicine, School of Medicine, Tehran University of Medical Sciences, Tehran, Iran. \\ *Corresponding author: Dr Vida Zaroushani, Social Determinants of Health Research Center, Qazvin University of Medical \\ Sciences, Qazvin. Iran. Email: v.zaroushani@qums.ac.ir. ORCID ID: 0000-0003-1713-4016
}

Received: 27 August $2019 \quad$ Accepted: 01 April 2021

\begin{abstract}
Background: Cancer is the main cause of death in developed countries and the second main cause of death in developing countries. The aim of this study was to review the occupational risk factors and cancer incident in Iran.

Materials and Methods: this present systematic review was done based on Preferred Reporting Items for Systematic Reviews and Meta-Analyses (PRISMA) guidelines on Persian articles with no time limits in publication and collected from January 2019 to April 2019 from Sid, Magiran and Google Scholar Databases. Some search terms including "job" or "occupation" "occupational exposure" or "cancer" or "neoplasm were used.

Results: A total number of 103 articles were detected. After applying the inclusion and exclusion criteria, finally 18 studies remained in this systematic review with 13897 sample size and 7187 diagnosed patients. Most included studies researched on non-melanoma skin as the most studied cancer and sunlight exposure as the most carcinogenic reported occupational risk factor. Among included researches, only four studies were directly related to occupational cancer with 1837 sample size and 604 diagnosed various cancers in workers that focused on kidney, bladder and mesothelioma cancers (Pleural mesothelioma and Perivascular mesothelioma) .The results showed that, the cancer was reported in some occupations more than others.

Conclusion: Most included researches reported skin cancer and exposure to sunlight as the most studied cancer and occupational risk factor respectively. As regard to importance of effective risk factors on cancer incidence , identification and control of occupational risk factor in the work environment should be a main key element of national cancer control program in countries specially developing countries. So it is recommended to develop the researches in field of occupational cancer in Iran.
\end{abstract}

Keywords: Exposure, Neoplasms, Occupational, Risk factor

\section{Introduction}

Iran is a developing country placed in the Middle East that may be affected by epidemiological patterns of various types of malignancy. Because of in the last years due to a fast growth of industrialization, and changes in the people's lifestyles and environment $(1,2)$. In Iran, cancer is the second largest group of chronic noncommunicable diseases and the third most common cause of death after heart disease, accidents and other natural phenomenon(2). Most workplaces in grow thing countries are not commonly inspected and laws for workers' protection are not accomplishment. However, research on occupational risks and the related cancer burden is essential in informal workplaces (3). Conforming to World Health Organization (WHO), each year 200000 people deceased duo to cancer related to their workplace) (4). Carcinogenic risks to humans evaluated by the International Agency for Research on Cancer (IARC) by related monographs that firstly published in 1972 (1) and evaluations through 2003, based on the occupational factors that classified as sufficient, probable, and possible human carcinogens $31 \%, 42 \%$, and $42 \%$, 
respectively (5). Since 2003, occupational factors continue to be highly prevalent (about $50 \%$ ) in new or upgraded IARC classifications (5). The international agency for research on cancer (IARC, 2002) has classified 150 chemicals or biological agents as known or probable human carcinogens, and exposure from many of these carcinogens (e.g. asbestos, cadmium and benzene) happened in occupational environment. Occupational exposure is impact to a potentially adverse physical, chemical, or biological agent as a result of one's work. Specific exposures are related to the type of work that people do (i.e. occupation), where they do it (e.g. the industrial section- also called the economic sector) and the measures that are taken to limit exposures (1). Although the number of known and suspected cancers are occupational cancer, determining occupational cancer risk factors are very important to program for the control and prevention of cancers .It is a high preference in health policy as well as it is recommended that earlier screening is needed for high risk people (2). In addition, according to WHO guidance, planning in cancer prohibition programs requires various data such as morbidity and mortality rates, most relevant causes and risk factors, and individual exposure routes (1). Lack of reliable and trusty data is an impediment to establish cancer prevention as a preference in public policies, therefore, this study was carried out to systematically review effective occupational risk factors on cancer in Iran.

\section{Material and Methods}

\section{Search strategy and study selection}

This present research was conducted based on PRISMA instruction.

The process focused a systematic review with a comprehensive and universal search strategy that carried out on Persian articles without time limits by two independent researchers and was collected from January 2019 to April 2019 in Sid, Magiran and Persian Google Scholar
Databases with following terms as search keywords (based on PICO principle) : "Job" or "Work" or "Occupation" or "Employ Worker" or "Technician" or "Staff "or "Occupational Exposure" or "Cancer" or "Neoplasm" or "malignant" or "Sickness" or "Disease" or "Risk Ratio" or" Odds Ratio".

\section{Inclusion and exclusion criteria}

Articles were attended for inclusion conforming to their study design and connection to the research questions. Studies were included if they were in design of case-control, cohort studies, randomized control trial (RCT) and descriptive studies referring to the association between occupation or worker and whole kind of cancer. The exclusion criteria were as follows: 1) case and field studies, reviews 2) studies with inhumane populations such as animal, in vivo and in vitro studies, 3) Studies on cancer risk modeling. 4) Studies on occupational exposure assessment to carcinogenic agents. 5) Studies in which did not investigate job/ work as one of the studied variables.

\section{Data extraction}

In the next step, duplicated studies were removed, then matching to the selection criteria, the title and abstract of the literature for the rebalance of the topics were surveyed.

Then, data extraction was done based on below information from selected papers: first author (year), origin by province, follow-up period, population, number of patients, study design, job title, population aging, cancer type, occupational effective factors, non-occupational effective factors

\section{Results}

\section{Search result and study selection}

A total number of 103 articles were detected in the prime step of literature review in SID, Magiran, and Persian Google scholar databases. After elimination of duplicated references, 78 
articles were included in the title, keywords and abstract screening. Then, 48 articles were excluded since they did not meet inclusion criteria. Therefore, 35 studies were selected for the competency evaluation. At the end of the selection procedure and after data extraction and processing, 18 studies remained in this systematic review that including 6 longitudinal studies $(1,2,4,6-8), 6$ casecontrol studies (11-16), 5 cross-sectional studies (17-21) and one cohort study (22) with no randomized control trial study .In addition, a manual reference check did not add any articles in this study. Figure 1 shows the flowchart of articles reviewed and selection flow in this systematic review.

\section{Included Studies characteristics}

The included studies in the present systematic review were conducted from 1993 to 2016 in several provinces of Tehran, Esfahan, Hamadan, Pars, Khuzestan, Mazandaran, Markazi, Razavi Khorasan, Yazd and Kurdistan with 13897 population, 7187 patients with a limit of ages 15-69 years that inquired the relation between occupational and nonoccupational risk factors and cancer. Summarized characteristics of included studies (longitudinal studies (6-11), casecontrol studies (12-17), cross sectional studies (18-22) and cohort study (23) were present in Tables 1.

Also the results showed that included studies were investigated on various cancers, including skin cancers $(6,8,10$, 20, 21 and 22), esophageal cancers $(2,8)$, bladder cancers $(12,16,22)$, brain cancer (18), colorectal cancers $(7,14)$, Brest cancer (13), and mesothelioma (Pleural mesothelioma and Perivascular mesothelioma) $(17,15)$ and kidney cancer (11). As be seen above, most included studies researched on skin cancer that focused on the non-melanoma skin cancer including Basal-cell carcinoma (BCC) and Squamous-cell carcinoma (SCC).

\section{Determined occupational risk factors}

It is mentionable that, the most included the researchers reported the sunlight exposure as the most carcinogenic occupational risk factor in this systematic review. Also, over exposure to asbestos, polycyclic aromatic, paint components, exhaust fume and pesticide fertilizer were other carcinogenic occupational risk agents for incidence cancer in included studies (Table 1).

About non-occupational carcinogenic risk factors, the finding showed that gender in 7 studies, cigarette, past medical history and patient location, each of them in 6 studies as well as patient's age in 5 studies were frequently reported by included studies. It is noteworthy that, in terms of gender, the men more than twice women to had cancer (Table I).

\section{Determined occupational cancer}

It is noticeable that among included researches, only four studies were directly related to occupational cancer that investigates on kidney, bladder and mesothelioma cancer (Pleural mesothelioma and Perivascular mesothelioma) in Tehran and Esfahan province $(11-12,15-16,17,22)$ with 1837 sample size and 604 diagnosed patients in female and male workers. in this review, involved occupants in the occupational cancers consists of workers in construction, farmers, housekeepers, manual workers, office workers, Workers in oil and gas industry and workers in related to Asbestos Insulation industries.

\section{Determined non-occupational risk factors}

About the age of patients, the finding suggested that in most included studies, the age in diagnosing patient was over 60 years. So that, in included studies that were conducted on bladder, skin, mesothelioma, kidney, and esophageal cancers diagnosed patient age was in the range of 60.39 to 65.45 years (Table I). 


\begin{abstract}
About study design, it is attractive that most included studies were designed with longitudinal $(1,2,4,6-8)$ and case- control studies (11-16).other studies were in design of cross sectional and cohort study that are shown Table 1. About job title, the results showed that agriculture in 8 studies, workers and housekeeping each of them in 6 studies were the most reported job
\end{abstract}

included studies (Table 1). About follow up period, the longest follow up period is related to Yazdanfar study (2011) with 1991-2007 follow up period that investigated on skin cancer (1). Other follow up periods in included longitudinal studies were 2(6), 3(4), 5(2), 6(8), 4(8), $7(7)$ in years.
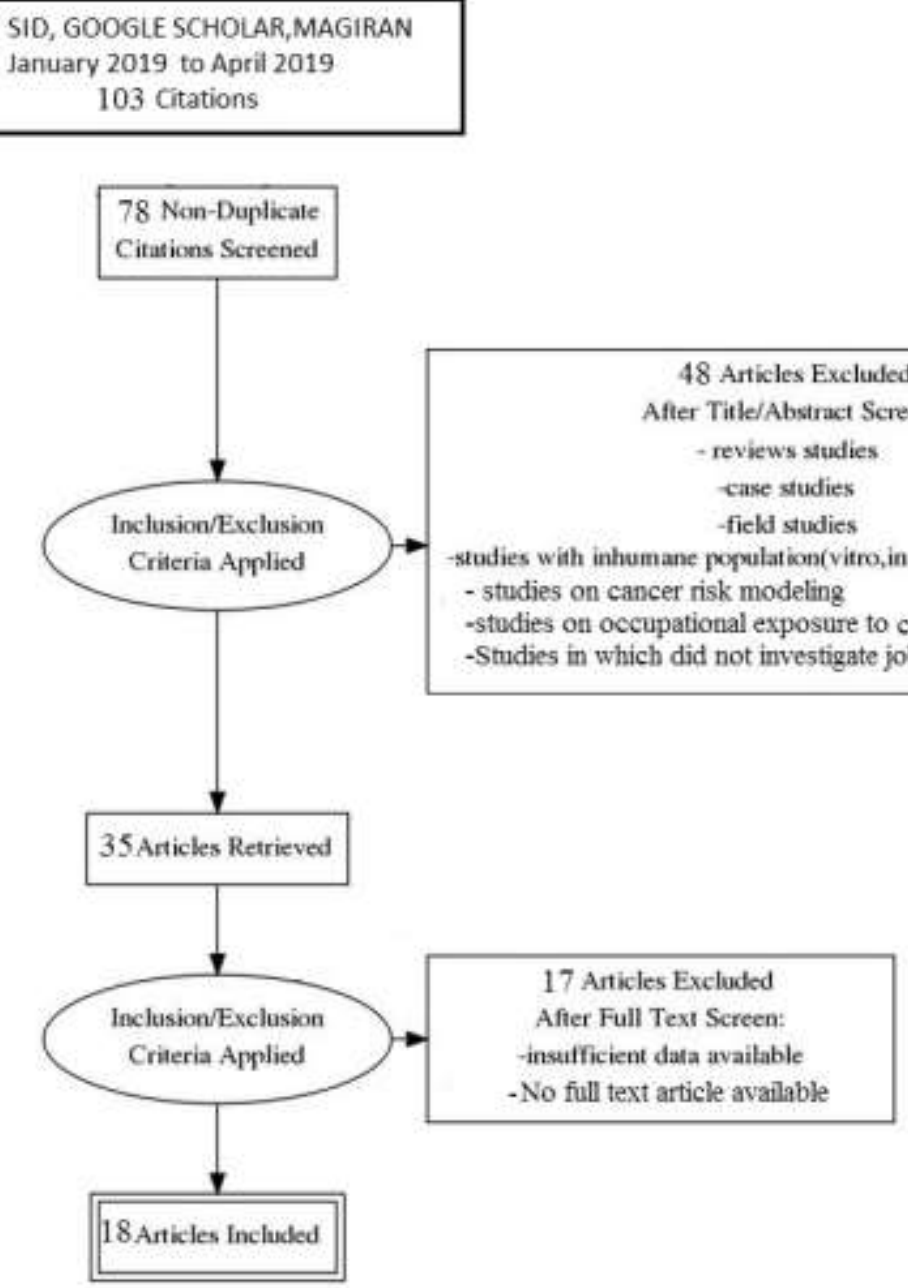

Figure 1. PRISMA Flow Diagram to present the process of generating this systematic review 


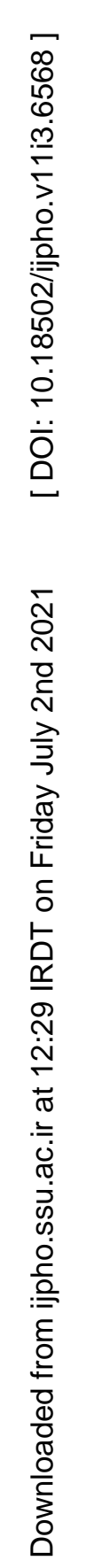


Table I: Characteristic of included studies in this systematic review

\begin{tabular}{|c|c|c|c|c|c|c|c|c|c|c|}
\hline 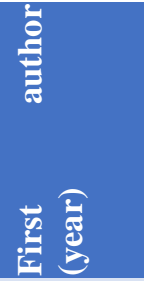 & 辰兽 & $\begin{array}{l}\frac{8}{0} \\
\frac{0}{0} \\
\frac{0}{7} \\
0 \\
\frac{0}{0} \\
\frac{0}{0}\end{array}$ & 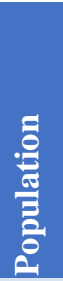 & 递苛 & 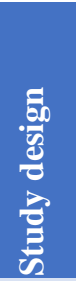 & $\begin{array}{l}\stackrel{0}{\Xi} \\
\stackrel{0}{0} \\
0\end{array}$ & 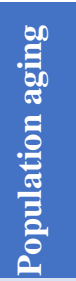 & 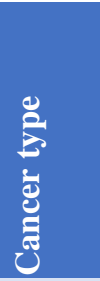 & 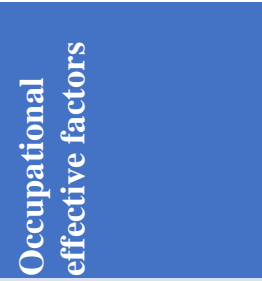 & 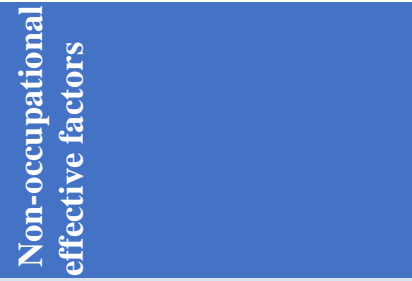 \\
\hline $\begin{array}{l}\text { Pouryag } \\
\text { houb, } \\
2014 \\
(17)\end{array}$ & Tehran & - & 272 & 60 & CS1 & $\begin{array}{l}\text { worker in } \\
\text { construction } \\
\text { industry ' } \\
\text { Worker in } \\
\text { oil industry ، } \\
\text { executive ' } \\
\text { driver، } \\
\text { tiler 'manual } \\
\text { worker, } \\
\text { worker in } \\
\text { Asbestos } \\
\text { Insulation } \\
\text { industries }\end{array}$ & 59 & $\begin{array}{l}\text { mesot } \\
\text { helio } \\
\text { ma }\end{array}$ & $\begin{array}{l}\text { Exposure to } \\
\text { Asbestos }\end{array}$ & $\begin{array}{l}\text { Smoking, residence place } \\
\text {,the proximity of Asbestos } \\
\text { cement manufacturing to } \\
\text { the residence place }\end{array}$ \\
\hline $\begin{array}{l}\text { Mina } \\
\text { Tajvidi, } \\
2013 \\
(11)\end{array}$ & $\begin{array}{l}\text { Esfaha } \\
n\end{array}$ & - & 643 & 180 & $\begin{array}{l}\mathrm{CC} \\
2\end{array}$ & $\begin{array}{l}\text { manual } \\
\text { worker، } \\
\text { executive ‘ } \\
\text { housekeeper } \\
\text { 'Farmer, } \\
\text { Animal } \\
\text { husbandry }\end{array}$ & 64 & $\begin{array}{l}\text { Kidne } \\
\text { y }\end{array}$ & $\begin{array}{l}\text { Exposure to } \\
\text { paint } \\
\text { components and } \\
\text { fertilizer }\end{array}$ & $\begin{array}{l}\text { smoking 'family history } \\
\text { kidney،past medical history } \\
\text { 'residence place ، source of } \\
\text { drinking water) }\end{array}$ \\
\hline $\begin{array}{l}\text { Yazdanf } \\
\text { ar, } 2011 \\
\text { (1) }\end{array}$ & $\begin{array}{l}\text { Hamad } \\
\text { an }\end{array}$ & $\begin{array}{l}199 \\
1- \\
200 \\
7\end{array}$ & 951 & 951 & $\begin{array}{l}\mathrm{LS} \\
3\end{array}$ & $\begin{array}{l}\text { manual } \\
\text { worker ‘ } \\
\text { housekeeper }\end{array}$ & 61.6 & skin & $\begin{array}{l}\text { Exposure } \\
\text { sunlight }\end{array}$ & Not reported \\
\hline
\end{tabular}

${ }^{1}$-Cross sectional study (CS study)

2 - Case Control Study ( CC Study)

3 - longitudinal study (LS study) 


\begin{tabular}{|c|c|c|c|c|c|c|c|c|c|c|c|c|}
\hline $\begin{array}{l}\text { Onsory, } \\
2011 \\
(18)\end{array}$ & Tehran & - & 200 & 100 & CS & $\begin{array}{l}\text { MRI } \\
\text { Radiologist }\end{array}$ & $\begin{array}{l}\text { Not } \\
\text { report } \\
\text { ed }\end{array}$ & brain & $\begin{array}{l}\text { Ove } \\
\text { to } \\
\text { over } \\
\text { mag } \\
\text { from } \\
\text { volt: } \\
\text { line, } \\
\text { to } \\
\text { facil }\end{array}$ & $\begin{array}{r}\text { exposure } \\
\text { X-ray, } \\
\text { exposure to } \\
\text { hetic field } \\
\text { high } \\
\text { ge power } \\
\text { Proximity } \\
\text { nuclear } \\
\text { ities }\end{array}$ & \multicolumn{2}{|c|}{$\begin{array}{l}\text { Excessive consumption of } \\
\text { meat, education level } \\
\text {,Excessive consumption of } \\
\text { alcohol, low pay, } \\
\text { Smoking, family history, } \\
\text { overweighting, Excessive } \\
\text { use of mobile phone, } \\
\text { proximity to mobile phone, } \\
\text { use of frying food, Vitamin } \\
\text { deficiency }\end{array}$} \\
\hline $\begin{array}{l}\text { Rajaee } \\
\text { fard, } \\
2009 \\
(2)\end{array}$ & Pars & $\begin{array}{l}200 \\
1- \\
200 \\
6\end{array}$ & 161 & 161 & LS & $\begin{array}{l}\text { farmer ' } \\
\text { Animal } \\
\text { husbandry) }\end{array}$ & 61.9 & $\begin{array}{l}\text { esoph } \\
\text { agus }\end{array}$ & \multicolumn{2}{|c|}{$\begin{array}{l}\text { Exposure to } \\
\text { Fertilizer and } \\
\text { soil pollutant to } \\
\text { nitrate }\end{array}$} & \multicolumn{2}{|c|}{$\begin{array}{l}\text { smoking ,past medical } \\
\text { history ,age }\end{array}$} \\
\hline $\begin{array}{l}\text { Valavi,20 } \\
13 \\
(19)\end{array}$ & $\begin{array}{l}\text { Khuzes } \\
\tan \end{array}$ & - & $\begin{array}{l}520 \\
1\end{array}$ & 602 & CS & $\begin{array}{l}\text { farmer ‘ } \\
\text { Animal } \\
\text { husbandry ' } \\
\text { Worker in } \\
\text { oil and gas } \\
\text { industry }\end{array}$ & 61 & Skin & \multicolumn{2}{|c|}{$\begin{array}{l}\text { Exposure to } \\
\text { sunlight }\end{array}$} & \multicolumn{2}{|c|}{ Age, gender } \\
\hline $\begin{array}{l}\text { Hajian,2 } \\
003 \\
(8)\end{array}$ & $\begin{array}{l}\text { Mazan } \\
\text { daran }\end{array}$ & $\begin{array}{l}199 \\
2- \\
199 \\
8\end{array}$ & 668 & 668 & LS & $\begin{array}{l}\text { farmer } \\
\text { manual } \\
\text { worker ' } \\
\text { executive }\end{array}$ & 62.8 & $\begin{array}{l}\text { esoph } \\
\text { agus }\end{array}$ & \multicolumn{2}{|c|}{ Job type } & \multicolumn{2}{|c|}{ Gender, job title } \\
\hline $\begin{array}{l}\text { Totonchi } \\
2000(12)\end{array}$ & $\begin{array}{l}\text { Esfaha } \\
\mathrm{n}\end{array}$ & - & 284 & 142 & $\mathrm{CC}$ & $\begin{array}{l}\text { worker it } \\
\text { exposure t } \\
\text { polycyclic } \\
\text { hydrocarbon }\end{array}$ & in & Bla & dder & $\begin{array}{l}\text { Exposure } \\
\text { Polycyclic } \\
\text { aromatic } \\
\text { hydrocarbon }\end{array}$ & & $\begin{array}{l}\text { High education, } \\
\text { residence place } \\
\text { 'smoking s taking tea, } \\
\text { frying food frequent } \\
\text { and chronic urinary } \\
\text { Infection ، family } \\
\text { history }\end{array}$ \\
\hline $\begin{array}{l}\text { Mobarak- } \\
\text { Abadi }\end{array}$ & $\begin{array}{l}\text { Markaz } \\
\text { i }\end{array}$ & $\begin{array}{l}200 \\
7-\end{array}$ & $\begin{array}{l}102 \\
6\end{array}$ & 958 & LS & $\begin{array}{ll}\text { worker } & \text { i } \\
\text { exposure } & t\end{array}$ & 65.4 & ski & & $\begin{array}{l}\text { Exposure } \\
\text { sunlight }\end{array}$ & to & Age, gender \\
\hline
\end{tabular}


Effect of occupational risk factors in cancer incidence in Iran: a Systematic Review

\begin{tabular}{|c|c|c|c|c|c|c|c|c|c|c|}
\hline ,2013(4) & & $\begin{array}{l}201 \\
1\end{array}$ & & & & sunlight & & & & \\
\hline $\begin{array}{l}\text { Ghasemza } \\
\text { deh,2017(6 } \\
\text { ) }\end{array}$ & Tehran & $\begin{array}{l}200 \\
7- \\
201 \\
5\end{array}$ & 865 & 865 & LS & $\begin{array}{l}\text { worker in } \\
\text { exposure to } \\
\text { sunlight }\end{array}$ & 65 & skin & $\begin{array}{l}\text { Overexposure to } \\
\text { sunlight (more } \\
\text { than 6-7 hours) }\end{array}$ & $\begin{array}{l}\text { Cardiac and } \\
\text { Metabolic } \\
\text { medical history } \\
\text { gender, residence } \\
\text { place }\end{array}$ \\
\hline $\begin{array}{l}\text { Fathi } \\
\text { Najafi , } \\
\text { 2004(13) }\end{array}$ & $\begin{array}{l}\text { Razavi } \\
\text { Khoras } \\
\text { an }\end{array}$ & - & 350 & 170 & $\mathrm{CC}$ & $\begin{array}{l}\text { teacher ' } \\
\text { manager , } \\
\text { Medical and } \\
\text { Religious } \\
\text { Jobs }\end{array}$ & 41.5 & Brest & Job type & $\begin{array}{l}\text { Age, residence place, } \\
\text { job title, job } \\
\text { experience, married } \\
\text { state, age, } \\
\text { First pregnancy, } \\
\text { Preterm childbirth } \\
\text { history, past medical } \\
\text { history, } \\
\text { Infertility } \\
\text { surgical history, } \\
\text { smoking. }\end{array}$ \\
\hline $\begin{array}{l}\text { Ajaz } \\
, 2003(22)\end{array}$ & Pars & $\begin{array}{l}199 \\
8- \\
200 \\
0\end{array}$ & 76 & 76 & $\begin{array}{l}\mathrm{CH} \\
4\end{array}$ & $\begin{array}{l}\text { farmer } \\
\text { manual } \\
\text { worker, } \\
\text { executive ' } \\
\text { housekeeper }\end{array}$ & 61 & bladder & Job type & Age, gender \\
\hline $\begin{array}{l}\text { Mohamma } \\
\text { di } \\
\text {,2017(20) }\end{array}$ & Yazd & - & 196 & 196 & $\mathrm{CS}$ & $\begin{array}{l}\text { Farmer ' } \\
\text { housekeeper }\end{array}$ & $\begin{array}{l}60.8- \\
62.1\end{array}$ & skin & $\begin{array}{l}\text { Exposure to } \\
\text { sunlight }\end{array}$ & $\begin{array}{l}\text { education level, low } \\
\text { pay, gender }\end{array}$ \\
\hline $\begin{array}{l}\text { Kazemi } \\
, 2015(21)\end{array}$ & $\begin{array}{l}\text { Kurdist } \\
\text { an }\end{array}$ & - & 866 & 866 & $\mathrm{CS}$ & $\begin{array}{ll}\text { worker } & \text { in } \\
\text { exposure } & \text { to } \\
\text { sunlight } & \end{array}$ & $\begin{array}{l}\text { classi } \\
\text { fied }\end{array}$ & skin & $\begin{array}{l}\text { Exposure to } \\
\text { sunlight }\end{array}$ & $\begin{array}{l}\text { Gender, residence } \\
\text { place }\end{array}$ \\
\hline $\begin{array}{l}\text { Salari } \\
\text {,2007(7) }\end{array}$ & Yazd & $\begin{array}{l}199 \\
2- \\
199 \\
9\end{array}$ & 191 & 191 & LS & $\begin{array}{l}\text { Housekeeper } \\
\text {, executive, } \\
\text { farmer, } \\
\text { worker }\end{array}$ & $\begin{array}{l}\text { classi } \\
\text { fied }\end{array}$ & $\begin{array}{l}\text { colorec } \\
\text { tal }\end{array}$ & & Not reported \\
\hline $\begin{array}{l}\text { Pourfarzi, } \\
\text { 2012(14) }\end{array}$ & Ardabil & - & 160 & 80 & $\mathrm{CC}$ & $\begin{array}{l}\text { executive ' } \\
\text { manual }\end{array}$ & $41-80$ & $\begin{array}{l}\text { colorec } \\
\text { tal }\end{array}$ & Job type & $\begin{array}{lr}\text { smoking } & \text { 'family } \\
\text { history, } & \text { consuming }\end{array}$ \\
\hline
\end{tabular}

${ }^{4}$-Cohort study (CH study) 


\begin{tabular}{|c|c|c|c|c|c|c|c|c|c|c|}
\hline & & & & & & $\begin{array}{l}\text { worker ' } \\
\text { housekeeper }\end{array}$ & & & & $\begin{array}{l}\text { carbohydrate, } \\
\text { 'Consuming } \\
\text { vegetables 'IgG+, } \\
\text { past medical history of } \\
\text { Inflammatory bowel } \\
\text { disease, Steroid Anti- } \\
\text { Inflammatory Drugs }\end{array}$ \\
\hline $\begin{array}{l}\text { Salehpour, } \\
2010 \\
\text { (15) }\end{array}$ & Tehran & - & 122 & 64 & $\mathrm{CC}$ & $\begin{array}{l}\text { worker in oil } \\
\text { and gas, } \\
\text { construction, } \\
\text { cement, } \\
\text { Asbestos } \\
\text { Insulation } \\
\text { industries ، } \\
\text { housekeeper }\end{array}$ & 60.39 & $\begin{array}{l}\text { mesoth } \\
\text { elioma }\end{array}$ & $\begin{array}{l}\text { Exposure to } \\
\text { asbestos }\end{array}$ & $\begin{array}{l}\text { Proximity of residence } \\
\text { place to asbestos and } \\
\text { cement manufacturing }\end{array}$ \\
\hline $\begin{array}{l}\text { Pourabdia } \\
\text { n,2010(16) }\end{array}$ & $\begin{array}{l}\text { Esfaha } \\
n\end{array}$ & - & 800 & 300 & $\mathrm{CC}$ & $\begin{array}{l}\text { Driver, } \\
\text { worker in } \\
\text { construction } \\
\text { (such as } \\
\text { welder, } \\
\text { stone } \\
\text { miller ') } \\
\text { farmer } \\
\text { housekeeper } \\
\text { house } \\
\text { cleaner }\end{array}$ & $35-93$ & bladder & $\begin{array}{l}\text { exposure to } \\
\text { Exhaust fumes, } \\
\text { herbicides and } \\
\text { insecticides, } \\
\text { exposure to } \\
\text { cutter oil, } \\
\text { containing } \\
\text { aromatic amines }\end{array}$ & Not investigated \\
\hline
\end{tabular}




\section{Discussion}

The present systematic review was done to study on effective occupational risk factors and incidence of cancers in Iran. A total of 18 studies were included (6 longitudinal, 6 case-control, 5 cross sectional studies and 1 cohort study) that were carried out from 1993 to 2016 with 13897 sample size and 7187 diagnosed patients $(51.72 \%$ of the studied population) that examined the relationship between occupational and non-occupational risk factors and cancer among patients.

The results of this systematic review presented that included studies commonly focused on non-melanoma skin cancers (Basal-cell carcinoma and Squamous-cell carcinoma) (1,4,6,19-21), esophageal $(2,8)$, bladder $(12,16,22)$, brain (18), colorectal (7, 14), Brest (13), mesothelioma (Pleural mesothelioma and Perivascular mesothelioma) $(15,17)$ and kidney cancer (11). Past research has shown that, "five most common cancers in Iranian males were prostate stomach, colorectal, bladder, breast, esophagus, colorectal, stomach, esophagus, and thyroid cancers are the most common cancers in females $(1,2)$.

In addition, this review finding showed that most included studies investigated about skin cancers (6 of 18 included studies) and only four research directly carried out on occupational cancer. In these researches, exposure and overexposure to sunlight (more than 6-7 hours) were reported as an effective occupational risk factor for skin cancer.

Moreover, the finding showed that nonoccupational risk factors containing age, gender, BMI, job title, past medical history (especially Cardiac and Metabolic past medical history), residence place, education level and low wages were reported as commonly non-occupational risk factors in the included researches about skin cancer.

It is interesting that the gender was the most common non occupational risk factor that reported on these researches $(4,6,8,19$ -
22). In terms of gender, the prevalence of cancer in men was more than twice of women. This result may be due to more exposure to sunlight in men because of their job title (Agriculture and Animal Husbandry) $(8,13,20,21,22)$.

High exposure to ultraviolet radiation (UV) can be the main reason for most skin cancers. Construction workers and agricultural that have most of their work time out of doors, may be at enhancements risk of skin cancer for UV exposure to high levels of the sun (24).

In addition to workplace policies, educational, behavioral, and environmental approaches are major interventions that are highly effective at decreasing sunburns and increasing sun-protection behaviors and among outdoor workers $(25,26)$. The result of one survey of construction workers showed an intervention by giving knowledge about safety in the sun exposure could affect significantly on their behavior (27). Therefore, these approaches could be used as effective administrative measures to sunlight exposure control at the workplaces.

Moreover, the certain factors, including cigarette, past medical history and patient location as well as patient age as other common non-occupational risk factors were frequently reported by included studies (Table 1).

Moreover, the results of this systematic review present that the related researches about occupational cancer in Iran are limited, such a way that few studies (6 of 18 included studies) were directly related to occupational cancer that investigated on kidney, bladder and mesothelioma cancer in Tehran and Esfahan province (11-12, $15-16,17,22)$ with 1837 diagnosed patients from 13897 sample size $(13.22 \%$ of studied population) conducted in this regard (Table 1).

It is noticeable that occupational cancer fact sheet of Canadian Centre for Occupational Health and Safety reported that the most general kinds of occupational 
cancer are lung cancer, bladder cancer and mesothelioma.

However, worldwide industrialization results in rising exposures to occupational carcinogens in developing countries, owing to hazardous technology or useless law on occupational safety and health (28). In line of occupational cancer risk factor, exposure to asbestos, paint components/fertilizer and exhaust fumes, herbicides and insecticides, cutter oil and containing aromatic amines were reported as the main occupational risk factor to infect by mesothelioma, kidney and bladder cancer respectively in the included studies (11-12, 15-16, 17, 22).

On mesothelioma cancer, exposure to asbestos was reported as the main occupational risk factor and the proximity of residence place to asbestos and cement manufacturing and smoking were reported as non-occupational risk factors $(15,17)$.

Also in kidney cancer, Exposure to paint components and fertilizer was reported as the main occupational risk factor and smoking, family history، past medical history, residence place and source of drinking water were reported as nonoccupational risk factors (11).

In this systematic review, it is shown that smoking was an effective nonoccupational risk factor for kidney cancer. After over two decades of increasing rates of kidney cancer incidence, trends worldwide show signs of plateauing or decreases in recent years, occupational exposure to solvent, cigarette smoking, Physical activity, obesity and hypertension can be an important risk factor for renal cancer although their relative impact may differ with several populations. This cancer generally is not considered an occupational disease, but elevated risk has been linked to certain occupations and exposure to a number of industrial agents (29).

About bladder cancer, exposure to exhaust fumes, herbicides and insecticides, exposure to cutter oil and containing and aromatic amines were reported as the main occupational risk factor with no effective non-occupational risk factors $(12,16,22)$.

In this article it is shown that bladder cancer (BC) in men was more than women and smoking an important risk factor. Bladder cancer is the 6th main general cancer in the universe and it is the 7 th most general cancer in men, and the 17th in women. The rate of $\mathrm{BC}$ diagnosis in men is 4 times greater than in women $(30$, $31)$.

Furthermore, tobacco smoking is one of the primary risk factors of bladder cancer in the world, particularly in the United States, and also it has become a concern in developing countries. The risk of developing $\mathrm{BC}$ in smokers was 3 times higher than non-smokers $(30,31)$.

In case of esophageal cancer, this systematic review showed that exposure to the nitrate and smoking in agriculture was the most important risk agents of esophageal cancer in studying Iranian workers similar to the other studies (32, 33). Esophageal cancer has a high mortality rate and a poor prognosis. Important risk factors include chronic gastric esophageal reflux disease, smoking and obesity. The important risk factors include smoking and alcohol use (32). Esophageal cancer is the eighth most common cancer worldwide. In nonindustrialized nations, nearly four out of five cases occur to Africa and Asia (34, $35)$.

This review showed that brain cancer risk factors can be obesity, occupation type and radiation. Also, past studies reported occupational associations between employment and brain cancer risk, too (36, 37). An increased risk of brain cancer has been reported in a number of recent studies among agricultural workers (38-40). Although one previous study suggested an elevated brain cancer risk, but this result was unexpected among workers in the printing and publishing industry, so it is better to be survey this topic because the printers are exposed to a variety of chemicals (41). 
About breast cancer, overweight and obesity are common risk factors (42). Additionally, the incidence of breast cancer is related to geographical region (43). The included study in this systematic review did not report the occupational risk factor related to breast cancer (18).

In our review, it is determined the cancers due to occupational exposures in the work environment have received short attention on Iran as a developing country (28).

So, the control of occupational risk factors of the workplace should be a key component of the national cancer control program in countries specially developing countries $(1,29)$. Thus, the WHO appreciates the policies used in some countries to prevent the use of carcinogens in the workplace. By providing the latest information to the ministries of health, the organization tries to regulate their health laws based on cancer prevention. The WHO recently issued an official statement to prevent a cancer epidemic in the coming years, warning countries to avoid asbestos and use safer materials such as pine fibers as an alternative (9).

Finally, it is important to note that these findings are based on a limited number of studies that did not report on occupational dose and duration of exposure. Therefore, it is reasonable to continue future studies on this topic and other articles in languages. The results of this study will be useful for strengthening occupational health policy.

\section{Conclusion}

This systematic review was conducted to study on effective occupational risk factors and incidence of cancers in Iran. This review finding showed that exposure and overexposure to sunlight were reported as an effective occupational risk factor for skin cancer. Also, this review showed that the related researches about occupational cancers did not consider seriously and were limited to a few studies that focused on kidney, bladder and mesothelioma cancer. The recognition and control of
Occupational risk factor of cancer in the workplace should be a main key element of national cancer control plan in countries specially developing countries.

\section{Acknowledgments}

This research was supported by Qazvin University of Medical Sciences. We sincerely thank Mr. Jalal Hassani Doabi for her tireless assistance.

\section{Conflicts of interest}

There are no conflict of interest in this research.

\section{References}

1. Yazdanfar A, Ghasemi E. Frequency of skin cancers in hamedan from 1991 to 2007. Dermatol Cosmet 2011; 2(2): 115123.

2. Rajaei F.A, Tabatabai S.H.R, Zeigami B, Safaie A, Tabeie S.Z. Evaluation of esophageal cancer registered cases in fars province (2001-2005). J Kermanshah Univ Med Sci 2009; 13(1): 65-73.

3. Ghasemzadeh F, Arab-kheradmand A, Daklan S, Shabaninezhad A, Garajei A, Etminani K. Determination of the most important factors affecting non-melanoma skin cancer using data mining algorithms. JHBMI 2017; 4(1): 39-47.

4. Mobarak-Abadi A, Rajabi R, Khani Y, Almasi-Hashiani A. Epidemiology of skin cancer in markazi province, Iran. Dermatol Cosmet 2013; 4(3): 120-126.

5.Blalr A. Occupational cancer in developed countries. In: Environmental Health. BioMed Central 2011;10(1):1-3.

6. Ghasemzadeh F, Etminani K, ArabKheradmand A, Hosseini Moini SB. A retrospective study on non melanoma skin cancer in cancer institute, imam khomeini medical center, tehran, Iran. Dermatol Cosmet 2017; 8(1): 9-21.

7. Salari A, Dehghan H. Evaluation and treatment of colorectal cancer in shahid rahnemoon and afshar hospitals, yazd-Iran. JSSU 2007; 15(3): 20-25.

8. Hajian $\mathrm{K}$. The epidemiologic investigation of patients suffering 
esophageal Cancer visiting Shahid Rajai radiotherapy center of Babolsar. J Gorgan Univ med sci 2003;5:73-9.

9. World Health Organization. WHO calls for prevention of cancer through healthy workplaces. Geneva: World Health Organization 2007.

10. Blair A, Marrett L, Beane Freeman L. Occupational cancer in developed countries. Environ Health 2011; 10 (1): S1-S9.

11. Tajvidi M, Najafi S, Molana S, Gharib S, Hemati S. The relationship of kidney cancer and occupation in isfahan province,iran; a case-control study. IUMS 2013; 31(229): 305-313.

12. Toutounchi M, Mazdak H, Najafipour $\mathrm{SH}$, Soleymani B. Bladder cancer risk factors among isfahan population: a casecontrol study. JRMS 2000; 5(2): 151-156.

13. Fathi Najafi T, Jabarzadeh Ganjeh S, Mojahedi Rezaian S, Mazloom SR. Lymphocyte subsets (cd3, cd4, cd8), cd4/cd8 ratio of sinus mucosa and measured serum ige level in adults. RJMS 2004; 11(42): 577-585.

14. Pourfarzi F, Yazdanbod A, Daneshvar $\mathrm{R}$, Saberi SH. Evaluation of effective factors in incidence of colorectal cancer. J Ardabil Univ Med Sci 2012; 12(5): 5664.

15. Salehpour S, Azin S, Cheraghvandi A, Heidari MM, Mohammad Sadegh S. Job and environment factors in relation with pleural malignant mesothelioma and determination of occurrence chance of mesothelioma in exposure to asbestos. IOH 2010; 7(2): 59-60.

16. Pourabdian S, Janghorbani M, Khoubi J, Tahjvidi M, Mohebbi I. Relationship between high risk occupation particularly aromatic amines exposure and bladder cancer in isfahan: a case-control study. Urmia Med J 2010; 21(2): 224-234.

17. Pouryaghoub G, Mehrdad R, Salehpour S, Shahryari M. Exposure to asbestos in patients with malignant mesothelioma in Iran. TUMS 2014; 72(2): 79-86.
18. Onsory K, Navabi S. The effect of environmental factors in the incidence of brain cancer. NCMBJ 2011; 1(3): 51-63.

19. Valavi E, Rafie S, Pakseresht P, Siadat S. Prevalence of skin cancer in southwest of iran. Koomesh 2013; 15(1): 83-88.

20. Mohammadi M, Mirzaie M, Barati $\mathrm{H}$, Mohammadzadeh M, Momeni Z, Drayafti $\mathrm{H}$, et al. The survey of status social and economic conditions of skin cancer in yazd, 2012. Nurse and Physician within War 2017; 4(13): 213-219.

21. Kazemi A, Eskandari O, Karimi M. Incidence rate and geographical distribution of skin cancer in kurdistan province of iran. Dermatol Cosmet 2015; 6(1): 38-45.

22. Ajaz A, Omid GK, Dastori P. The rate of relapse and its predictive factors in superficial bladder cancer in shahid faghihi hospital in shiraz during 1997-1999. J Zanjan Univ Med Sci 2003; 11(42): 1-9.

23. Rushton L, Hutchings SJ. The burden of occupationally-related cutaneous malignant melanoma in britain due to solar radiation. Br J Cancer 2017; 116(4): 536539.

24. Health UDo, Services H. The surgeon general's call to action to prevent skin cancer. U.S. Public Health Service 2014;1112

25. Ragan KR, Lunsford NB, Thomas CC, Tai EW, Sussell A, Holman DM. Skin cancer prevention behaviors among agricultural and construction workers in the united states, 2015. Prev Chronic Dis 2019; 16(E15): 1-14.

26. Houdmont J, Madgwick P, Randall R. Sun safety in construction: a uk intervention study. Occup Med 2015;66(1):20-26.

27. Merletti F, Galassi C, Spadea T. The socioeconomic determinants of cancer. Environ Health 2011; 10 (1): S1-S7.

28. Chow WH, Dong LM, Devesa SS. Epidemiology and risk factors for kidney cancer. Nat Rev Urol 2010; 7(5): 245-257. 29. Burger M, Catto JW, Dalbagni G, Grossman HB, Herr H, Karakiewicz P, et al. Epidemiology and risk factors of 
urothelial bladder cancer. Eur Urol 2013; 63(2): 234-241.

30. Letasiova S, Medvedova A, Sovcíkova A, Dusinska M, Volkovova K, Mosoiu C, et al. Bladder cancer, a review of the environmental risk factors. Environ Health 2012; 11(1): S1-S11.

31. Short MW, Burgers KG, Fry VT. Esophageal cancer. Am Fam Physician 2017; 95(1): 22-28.

32.Vingeliene S, Chan DS, Vieira AR, Polemiti E, Stevens C, Abar L, et al. An update of the WCRF/AICR systematic literature review and meta-analysis on dietary and anthropometric factors and esophageal cancer risk. Ann Oncol 2017; 28(10): 2409-2419.

33.Jansson C, Johansson ALV, Bergdahl IA, Dickman PW, Plato N, Adami J, et al. Occupational exposures and risk of esophageal and gastric cardia cancers among male Swedish construction workers. Cancer Causes\& Control 2005; 16(6): 755-764.

34.Kamil N, Kamil S. Global cancer incidences, causes and future predictions for subcontinent region. Sys Rev Pharm 2015; 6(1): 13-17.

35. Rolland-Harris E, Simkus K, Weeks M. Burden of cancer mortality in the canadian armed forces, 1976-2012: a retrospective cohort study. Cancer Epidemiol Biomarkers Prev 2019; 28(8): 1364-1369.

36. Oddone E, Alessandra S, Edoardo B, Carlo M, Fabrizio S, Giuliano M, Paolo C, Marcello I . Occupational brain cancer risks in Umbria (Italy), with a particular focus on steel foundry workers. G. Ital. Med. Lav. Ergon 2014; 36(2): 111-117.

37. Miranda F, Adalberto LM, Gina T R, Meyer A. Brain cancer mortality among farm workers of the State of Rio de Janeiro, Brazil: a population-based casecontrol study, 1996-2005. Int J Hyg Environ Health 2012; 215(5): 496-501.

38.Lee S. J. The occupational diseases of agricultural workers. Hanyang Med Rev 2010;30(4): 305-312.
39. Gomes J, Al Zayadi A, Guzman A. Occupational and environmental risk factors of adult primary brain cancers: a systematic review. Int $\mathrm{J}$ Occup Environ Med 2011; 2(2): 82-111.

40. McLean D, Fleming S, Turner MC, Kincl L, Richardson L, Benke G, et al. Occupational solvent exposure and risk of meningioma: results from the interocc multicentre case-control study. Occup Environ Med 2014; 71(4): 253-258.

41. DeSantis CE, Lin CC, Mariotto AB, Siegel RL, Stein KD, Kramer JL, et al. Cancer treatment and survivorship statistics, 2014. CA Cancer J Clin 2014; 64(4): 252-271.

42. Meisner AL, Fekrazad MH, Royce ME. Breast disease: benign and malignant. Med Clin North Am 2008; 92(5): 11151141. 